\title{
XVIII
}

\section{Like a Shepherd to His Flock: The Messianic Pedagogy of Fyodor Dostoevsky-Its Sources and Conceptual Echoes}

\author{
Inessa Medzhibovskaya
}

In fond memory of Robin Mookerjee-wordsmith, poet, friend, a remarkable mentor to students and colleagues

A disciple is not above his teacher, but everyone who is perfectly trained will be like his teacher... For a good tree does not bear bad fruit, nor does a bad tree bear good fruit -Gospel of Luke 6:40, 43, 44

Plants are shaped by cultivation, and men by education. -Jean-Jacques Rousseau (1762). ${ }^{1}$

We have realized the necessity of uniting with our native soil, our popular foundations. Our aim is to create a new form for ourselves, our own, native form, derived from our own soil.

1 Jean-Jacques Rousseau, Émile, or On Education, trans. and intro. Allan Bloom (New York: Basic, 1979), 38.

2 “Ob'iavlenie o podpiske na zhurnal Vremia na 1861," in F. M. Dostoevsky, Polnoe sobranie sochinenii v tridtsati tomakh [PSS], ed. V. G. Bazanov et al. (Leningrad: Nauka, 1972-1990), 
Oswald Spengler's The Decline of the West (1918) is remembered mainly for its doomsday verdict on Western culture. It is less known, however, for a place reserved in it for Dostoevsky's posthumous leadership in the new millennial Reich. Since the "history of higher mankind fulfills itself in the form of great culture," which lasts roughly a millennium, the future belongs to Russia, the Russia of Dostoevsky: "To Dostoevsky's Christianity will the next thousand years belong." 3 It is tempting to explain Spengler's admiration for Dostoevsky by his proven dependence on Hippolyte Taine, the inventor of theories of the rise and decline of historic-cultural types and of racism in culture. Dostoevsky was also influenced by Taine and was well familiar with his De l'intelligence and L'Ancien Régime (PSS, 27:113, 377; 30[1]:30). But I will take another route.

At the turn of the century in German-speaking lands, every significant artist and thinker nurtured on Nietzsche's affirmation of suprahistorical heroism was simultaneously looking for a way out of the stalemate faced by cultures of liberal democracy. ${ }^{4}$ The humanistic ideals of Goethean Weimar did not produce citizens of the world but a society of professionals, public servants, and consumers. Nietzsche likens their state of mind to the happiness of masticating cattle, curious about the world beyond the slope only to the extent that richer outlying pastures could be found. With matching scorn, Dostoevsky satirizes German Bildungsbürgertum alongside the hedonistic frivolity of the French bourgeois in Winter Notes on Summer Impressions (1862) (PSS, 5:46-98). According to Georg Lukács, Nietzsche and Dostoevsky were providing the answers to unfulfilled revolutionary yearnings of a bourgeois man born around 1870 (the same year as Lenin) _ “the generation whose formative literary influences were Dostoevsky and Nietzsche and who has not moved from the anti-liberal apostasy fashionable at the time."

18:36. Unless otherwise noted, this and all further references to Dostoevsky's work are to this academic edition, cited as PSS by volume and page.

3 Oswald Spengler, The Decline of the West, trans. Charles Francis Atkinson, rev. Arthur Helps, ed. Helmut Werner (New York: Vintage, 2006), 81, 273-74.

4 I mean primarily the arguments in Nietzsche's "On the Uses and Disadvantages of History for Life" and "Schopenhauer as Educator" in his Untimely Meditations (1874); see Friedrich Nietzsche, Untimely Meditations, trans. R. J. Hollingdale; ed. Daniel Breazeale (Cambridge: Cambridge University Press, 2000), 57-194.

5 Georg Lukács, "In Search of a Bourgeois Man," in Essays on Thomas Mann, trans. Stanley Mitchell (New York: Grosset and Dunlap, 1964), 34. 
No wonder, therefore, that instead of returning to the patrician equanimity of Goethe's Weimar in the maiden days of the Weimar Republic, Thomas Mann found his ideal in Dostoevsky's method "relating to the national necessity for a religious ideal transcending individual prosperity." 6 When asked in 1919 to comment on the growing success of his work in the Bildungsroman genre, Mann's friend Hermann Hesse chose to defer to the author of The Brothers Karamazov as the true leader of European youth, whose ideal was beginning to devour the spirit of Europe:

The young people of Europe, and especially the youth of Germany, feel Dostoevsky to be their great writer, not Goethe, not even Nietzsche.... This is what I call the decline of Europe. ... Briefly put, it is a turning away from every fixed morality and ethic in favor of a universal understanding, a universal validation, a new, dangerous, terrifying sanctity such as the elder Zosima. ${ }^{7}$

A twenty-five-year-old Walter Benjamin, the very representative of that young generation, had stated the core of the matter even more succinctly in 1917. His novel of choice was The Idiot:

Dostoevsky depicts the destiny of the world in the medium of the destiny of the people. This point of view is typical of the great nationalists, according to whom humanity can unfold only in the medium of a national historical heritage ... in the aura of the Russian nation. ${ }^{8}$

These tendencies in the German wave of enthusiasm for Dostoevsky at the turn of the century and in the interwar period are more than simply intriguing. They require a serious assessment of Dostoevsky's messianism, which hinges on his conviction that European civilization brings new elements into Russian popular life by widening its horizons rather than luring it away from its predetermined route. In the best traditions of classical liberalism, he believes that the receipt of a

6 Mann notes this idea in the diary entry of January 21, 1920; Thomas Mann, Diaries, 1918 1939, selection and foreword Hermann Kesten; trans. Richard and Clara Winston (London: Robin Clark, 1984), 84.

7 Hermann Hesse, "The Brothers Karamazov, or The Decline of Europe: Thoughts on Reading Dostoevsky," in My Belief: Essays on Life and Art, trans. Denver Lindley, ed. and intro. Theodore Ziolkowski (New York: The Noonday Press, 1975), 70-71.

8 Walter Benjamin, "Dostoevsky's The Idiot," in Early Writings, 1910-1917, trans. Howard Eiland et al. (Cambridge, MA: Belknap, 2011), 275-80. Written in 1917, the Benjamin's note was published in 1921. 
diploma does not complete the soul (PSS, 21:128). It may appear that Dostoevsky therefore can no longer be reduced to a simple commitment to the ideology of the soil (pochvennichestvo) taken strictly in its Russian historical context. ${ }^{9}$ But the picture is more complex. For the same reason as he was inspiring the Germans before 1933, Dostoevsky had failed as a leader in the eyes of Russian liberal youth. Consider a previously overlooked formative episode in the career of Paul Miliukov, the future leader of the Constitutional Democrats and a major force in Russian politics before November 1917, later a renowned historian following his emigration from Russia. On April 3, 1878, the meat packers of Okhotnyi Riad, a historical trader row in the heart of Moscow, assisted the police in the beatings of students who were peacefully demonstrating in a procession from the Kursk Railway Station in Moscow to demand freedom and better options for their education. After the brutal crackdown, Miliukov and five other students addressed Dostoevsky directly. They wanted to know whether the meatpackers' action was a legitimate response of the Russian people (henceforth narod) to the intelligentsia. ${ }^{10}$

Unexpectedly, in his response on April 18, 1878, Dostoevsky blames the victims, the beaten youths, for thinking with the brain of a European "Man-in-General" (obshchechelovek) (PSS, 30[1]:21-25), and for not recognizing the hand of the Russian people in the meatpackers who struck them (30[1]:23). Dostoevsky went as far as to brand the flogged students "les moutons de Panurge" (Panurgovo stado) (30[1]:22), implying that the demonstrators followed blindly towards their destruction after the first discarded sheep in their flock went overboard. ${ }^{11}$ (Note that Dostoevsky is not dealing with a Schillerian "All-Man" (vsechelovek), but with a commonality, the "Man-in-General"). Miliukov and fellow students realized that their faith in

9 I discuss Dostoevsky within the contexts of Russian debates and polemics on education in his time and the important outlines of his views on education in his works of fiction in Inessa Medzhibovskaya, "Education," in Dostoevsky-in-Context, ed. Deborah Martinsen and Olga Maiorova (Cambridge: Cambridge University Press, 2015), 106-13. For reasons of space, in this chapter I limit to the necessary minimum the discussion of Dostoevsky's creative fiction.

10 The students' letter appeared in Fyodor Dostoevsky, Pis'ma, ed. and commentary A. S. Dolinin (Moscow: Gosizdat, 1928-59), 4:355-56.

11 See book 6, chaps. 6-8 of François Rabelais's Gargantua and Pantagruel, recounting the wrangling of Panurge and Dindenault over the ownership of the herd of sheep. When trickster Panurge throws one sheep into water, the rest of the herd blindly follows; see François Rabelais, Gargantua and Pantagruel, trans., ed., and intro. M. A. Screech (London: Penguin, 2006), $680-87$. 
Dostoevsky was misplaced, that they could not subscribe to the proposed idolatry of the ultraconservative, violent, and monarchist tendencies of Dostoevsky's God-bearers. ${ }^{12}$

In Diary of a Writer for 1873, Dostoevsky brings up Gogol's "Nevsky Prospect" ("Nevskii Prospekt," 1833-34), in which a frivolous Lieutenant Pirogov receives a hearty flogging from locksmith Schiller, a German operating his business in St. Petersburg, for chasing after his wife through the glittery mists and snow flurries of the wintry capital. For Dostoevsky, Gogol's fantastic anecdote is no laughing matter because he retells it to impress upon the reader that the thrashing received by Pirogov from Schiller should be taken seriously, as a "terrifying prophesy" into the future of Russia and its two-hundred-year habit of being "spat at in the face" by Europe (PSS, 21:124). The choice of names is not coincidental: in Diary of a Writer for 1876, Dostoevsky was arguing that another Schiller, the great Friedrich Schiller, not a locksmith but a surgeon by trade, was one great example of an All-Man, a cosmopolitan citizen of the universe (vsechelovek) who had left the impression of his trademark (kleimo) on the soul of Russia as a token of its readiness for life in world culture. It is good then that another historical prototype of Dostoevsky's drafts, field surgeon Nikolai Pirogov, hero of the Crimean campaign, later head of the Odessa and Kiev educational districts, was a flogger by conviction and in practice. It is not only that Dostoevsky defends Pirogov's doting authoritarianism from the liberal and democratic attacks and supports flogging $(19: 69,268 ; 20: 158-61) .{ }^{13}$ In Diary of a Writer for December 1876, Dostoevsky responds to the coverage of a peaceful student demonstration in Moskovskie Vedomosti in which editor Mikhail Katkov dismissed the demonstration as a demarche of an "egged-on herd" (nastegannoe stado) — translated more literally, "a herd flogged so as to be induced into obeying an external ill will.” Dostoevsky does not dispute the very use of the flogging metaphor, which implies underhandedly that the students

12 P. N. Miliukov, Vospominaniia (1859-1917), 2 vols., ed. M. M. Karpovich and B. I. El'kin. (New York: Izdatel'stvo imeni Chekhova 1955), 1:62-63, 68. Writing his memoir years after the events, Miliukov remembers incorrectly the date of their address to Dostoevsky, which occurred in 1878, not 1876 (ibid., 62).

13 See Dostoevsky's "Bov and Pirogov," in his Notebook for 1860-62 (PSS, 20:162-68), and other notations in the same notebook regarding the Pirogov question (PSS, 20:153-56, 158-61) in response to Dobroliubov's "The Illusions of All-Russia Destroyed by Birch-Rods" ("Vserossiiskie illiuzii, razrushaemye rozgami," 1860). 
misbehaved precisely because they were an "unflogged herd," spoiled by their complacent educators (24:50-54).

These episodes illustrate the direct connections that Dostoevsky makes among cultural borrowing, politics of native soil, traditions of national dignity, discipline, the leadership role of the shepherd, and his authority. He explains pochvennichestvo itself as a vehicle of his messianic educational project. Thus, he interprets the triumph of his famous "Pushkin Speech" (1880) as a "victory of our idea" [pobeda nashei idei], that is, the victory of the idea of pochvennichestvo. ${ }^{14}$ In preparatory drafts for the speech and in the speech itself, Dostoevsky reflects on the homelessness of Aleko, the superfluous fugitive from the shackles of the Enlightenment in Pushkin's narrative poem "Gypsies": "He has no soil for support under his feet” ( u nego nikakoi pochvy) (PSS, 26:143). To become a true Russian is to become universal (vselenskii), like Pushkin, "the great teacher" of the Russian nation, who was capable of responding to all humanity, and of absorbing lessons from the common Russian people (1880) (26:47; 151-53). Pushkin's note "On Popular Upbringing” (“O narodnom vospitanii," 1826) first appeared in print in 1872, and its resonance was great, coinciding with Dostoevsky's preoccupation with the question of whether popular education should be enforced. ${ }^{15}$ In the note, submitted privately to Nicholas I after the suppression of the Decembrists, Pushkin insists on the advantages of the government's boundless might with respect to the application of top-down Enlightenment, but without coercion; he also protests against corporal punishment.

By following Pushkin, Dostoevsky chooses to overlook authoritarian violence. His chief goal is to illuminate the original sense of the Russian word "enlightenment" (prosveshchenie), which is the enlightening of the flock (pouchenie pastvy). ${ }^{16} \mathrm{He}$ responds effusively to the "toothless liberal skepticism" of historian Alexander Gradovsky: "You have uttered an important word: Enlightenment.

14 See Dostoevsky's letter to A. G. Dostoevskaya of June 8, 1880, PSS, 30(1):184-85.

15 See Pushkin, "On narodnom vospitanii," in A. S. Pushkin. Polnoe sobranie sochinenii, 19 vols.; reprint of A. S. Pushkin, Bol'shoe akademicheskoe izdanie, ed. D. D. Blagoi, S. M. Bondi, G. O. Vinokur et al. (Moscow-Leningrad: Izdanie Akademii Nauk SSSR, 1937; Moscow: Vozrozhdenie, 1994-97), 11:43-47.

16 It is in this sense that Pushkin commends enlightenment in his comments on the activity of Grigorii Konisky, the archbishop of Byelorussia under Catherine the Great; see Pushkin, Polnoe sobranie sochinenii, 12:14. See the definition of words "to enlighten" (prosvetit'), "the enlightener" (prosvetitel') and "enlightenment" (prosveshchenie) in Vladimir Dal's famed Russian thesaurus, which came out in 1863-66; see V. I. Dal', Tolkovyi slovar' velikarusskogo iazyka 
Allow me to ask how you mean: Western sciences, useful knowledge, professional handicrafts or spiritual Enlightenment?" (PSS, 26:150). In the latter sense, Dostoevsky is sure that "our narod was enlightened already a long time in the past, having embraced Christ and His teaching" (Diary of a Writer, 1880; 26:150). In the autobiographical sketch "Peasant Marey" published in his Diary of a Writer, Dostoevsky tells us an indirect parable about popular Russian enlightenment. The words "Je hais ces brigands!," about thieving Russian commoners led out for flogging and addressed to him in French in the barracks of the Siberian camp by an educated Pole, make Dostoevsky recall the words of kindness received by him, a fearful little boy, from peasant Marey. He encounters Marey in the fields during his panicked flight from imagined wolves. Patting the boy's face with his unwashed fingers soaked in black native soil—an important detail—and in a tone of unusual kindness, Marey tells him never to be frightened (February 1876; 22:46-50).

Alongside his recovery of the original Russian meaning of prosveshchenie, Dostoevsky pays equal attention to the importance of the other two Russian words, "education" proper (obrazovanie), and "upbringing" (vospitanie). These two also carry a considerable cultural-semantic weight that is crucial for understanding Dostoevsky's messianic program. The former connotes prima facie the process of "shaping" and "forming" rather than simply providing one with the knowledge and techniques of learning. Its semantic root is obraz ("image, face, shape"), which readily associates with religious aspects of holiness and beauty—and in that case may become synonymous with another Russian word, lik, a "saintly visage," "a face painted on an icon." ${ }^{17}$ The word vospitanie connotes the condition of having received the nourishment (bodily and soulful) without which it is impossible to grow, and only then does it underscore the acquisition of secular forms of conduct and of social skills. ${ }^{18}$ Yet again, Dostoevsky privileges the spiritual and moral content of both terms by claiming that anyone educated and with the right upbringing is not only capable of discriminating good from evil but is also well armed to confront evil. Such an understanding of these Russian words hearkens back to the ancient Greek paideia and its later Patristic overtones, underscoring the process and science of raising and leading children towards knowledge by training

Vladimira Dalia, 3rd ed., corrected by I. A. Baudouin de Courtenay (St. Petersburg-Moscow:

Tovarishchestvo M. O. Vol'fa, 1907), 3:1327.

17 Dal', Tolkovyi, 2:1580-81.

18 Ibid., 1:610. 
them the skills for life. By assuming that the traditional Russian Enlightenment leads the flock, Dostoevsky objects to the opinion of a conservative critic V. D. Skariatin that in its regular communal ways and even in its radical gestures the Russian nation resembles a herd (PSS, 20:70).${ }^{19}$ Even in its backwardness Russia was distinct. Despite the Russians so-called barbarism, the Genevan Franz Lefort, Peter's Westernizing mentor, decided to focus his great educational experiment on the young tsar and his nation (18:42).

Dostoevsky conceives of Peter the Great as the only modern Russian leader (vozhàtai $[s i c]$ ) who had proved himself in the role of the conductor of the nation walking the road of secular enlightenment. Having walked to the end of this modernizing road of sheer borrowing, the narod has been left without shepherds (bez vozhataev). The new forms of life (novye formy zhizni) that resulted from the disorderly creativity of a leader-less narod are repellent, have lost their face (bezobrazny) (PSS, 18:36). Only the education rooted in the highly moral upbringing (vysokonravstvennoe vospitanie) of Russian Orthodoxy sponsored by the tsar and the government could restore the face (obraz) of the people (20:122). Therefore, in the 1870s Dostoevsky accepted in good faith Minister of Enlightenment Dmitry Tolstoy's policy of returning to the classical and deliberately antiprogressive education model: "We have still to educate ourselves much to be considered truly Russian” (ibid.). At the same time, Dostoevsky's messianic ideology overemphasized the preservation of svoe ("the native element") (20:21).

In his address to "fathers and teachers" in Alyosha Karamazov's notes of the same,${ }^{20}$ the elder Zosima uses the term "enlightenment" strictly in the original Patristic sense of the accomplished illumination of the flock in the "joys and heroic deeds of Enlightenment and charity" (radosti v podvigakh prosveshcheniia $i$ miloserdiia) (PSS, 14:288). Untouched by the light of spiritual reality, the secular education of the "superfluous" and their science confirm at best what is

19 See Dostoevsky's responses and objections in Vremia (PSS, 20:59-70) to Slavophiles and Westernizers: "Two Theoretical Camps" ("Dva lageria teoretikov") and "On New Literary Organs and Theories" ("O novykh literaturnykh organakh i o novykh teoriiakh"), the latter of which includes his response to Skariatin's piece "On the Herd Qualities of Russian Man" ("O tabunnykh svoistvakh russkogo cheloveka").

20 As Dostoevsky's narrator puts it, he prefers to limit the discourses to the rendition based on the manuscript of "Aleksey Fedorovich Karamazov. It will be shorter, and not as tedious, although, and I must repeat this, much of it was taken by Alyosha from the previous discourses" and he "joined them into a harmony [sovokupil vmeste]" (PSS, 14:260). 
already prompted by divine intuition (14:284-86). What has been lost in the "teaching of this world," which trains one only for the "freedom of sating one's demands" (14:284), must be restored through the power of the "brotherhood and integrity of the human beings" (bratstvo i tselostnost' liudei) who are educated (obrazovany) in the image of Christ (obraz Khristov) (14:284), well preserved in the people, the God-bearer (narod-bogonosets), and in the monasteries which spread Christ's teaching.

Like his Zosima, Dostoevsky is reluctant to dissociate the discussions of "the highest meanings of life" (vysshii smyls zhizni) from practical tasks (prakticheskie zadachi) (PSS, 24:50-52). He agrees that the "literate common folk" (gramotnoe prostonarodie) are the most reverent and judicious consumers of "the spiritual bread" of education (1861) (18:60-67), but he steers clear not only of utilitarian simplifications committed by civic critics like Dobroliubov and Chernyshevsky but also of the anarchic religiosity of Leo Tolstoy. Tolstoy is fine with peasant charges being taught by "pilgrims, clerics, soldiers." ${ }^{21}$ Tolstoy's choice of educational roles in his 1874 essay on popular education-read by Dostoevsky in 1878 in the early stages of his drafting of Zosima-is an accurate and subversive recycling of the dramatis personae (pilgrims, clerics, soldiers) of Denis Fonvizin's immortal comedy The Minor (1782). The group consists of teachers to the unenlightened and slow-witted landowner son, Mitrofan Prostakov, the national symbol of gluttony, arrogance, and vice. Dostoevsky disagrees with Tolstoy's propositions regarding who should teach peasants by the proverbial "natural method." The method of this type would do little to arm the Russian populace with up-to-date knowledge ready to undertake the task of its theophanic liberation of the world. Minister Dmitry Tolstoy and Dostoevsky could agree, but Leo Tolstoy and Dostoevsky could not. In his first essay on popular education of the same name, written in 1862, Tolstoy (the writer) postulated his objection to the principles of autocratic pedagogy in the monarchy that maintained "not the shepherd for the flock, but the flock for the shepherd."22

How do we measure Dostoevsky's pedagogical messianism by comparison to his predecessors and contemporaries, on the one hand, and to some important later extensions, on the other? Was his messianism unique? It does not take long

21 L. N. Tolstoy, Polnoe sobranie sochinenii, Jubilee Edition in 90 vols., ed. V. G. Chertkov et al. (Moscow: Khudozhestvennaia literatura, 1928-58), 17:128.

22 Ibid., 8:4-25 
to notice a multitude of resonances with other artists and thinkers who are as open as Dostoevsky to an authoritarian cultural borrowing in making the foreign (chuzhoe) become their own or, in the case of making the claim for national destiny, Russia's own (svoe) (PSS, 19:141).

The great Germans who furnished the ideas of Bildung to prepare the foundation of their national culture within the framework of modern humanism quite similarly claimed their exclusionary capacity among the enlightened folk (Volk, same as narod) for putting the principles of Greek paideia in their missionary employ. ${ }^{23}$ It takes remembering Herder's categories of Bildung (logical, moral, political) to notice their imitation of the liberal arts concepts of paideia explained by Aristotle in Nichomachean Ethics (1337a-1338b). ${ }^{24}$ In much the same manner, Dostoevsky claims that through the finest modification of the cultural treasures of its European teachers, Russia alone is destined for the role of their most deserving disciple. (In place of Dostoevsky's Pushkin, the Germans place Goethe, their version of a universal genius.) Even more striking are the similarities of Dostoevsky's nationalist education schemes with those of Fichte and Hegel. Recall Headmaster Hegel's address to a gymnasium audience at Nuremberg in 1809 and Fichte's speeches to the German nation under Napoleon in 1813.

Let Hegel be the first to speak:

The spirit and purpose of our foundation is preparation for learned study, a preparation grounded on Greece and Rome. For more than a thousand years this has been the soil on which all civilization stood, from which it has sprung,

23 On this feature of German messianism, see Werner Jaeger, Paideia: The Ideals of Greek Culture, 2nd ed., trans and ed. Gilbert Highet (Oxford: Oxford University Press, 1973), 1:xxiii-xxix. The figure of an educator who leads and cultivates a harmonious human being is crucial for the focus on a connective link between the oneness of all and the multiplicity of the world, of ideas (eidos) and the images they generate (eikones). The modern German term Bildung, born during the days when Germany was seeking to become a unified nation, embraces the meanings of "formation," "shaping," "education," and "cultivation." It is thus a gathering into one word of the Greek paideia and the Latin educatio, which signifies cultivation alongside instruction, the leading and conducting of somebody's growth. The German adjective gebildet, according to Gadamer's classic analysis, is not being said of someone who is simply educated, but of someone who becomes "open to the universal sense"; Hans-Georg Gadamer, Truth and Method, 2nd rev. ed., trans. and revised Joel Weinsheimer and Donald D. Marshall (New York: Continuum, 1988), 17. For the historical changes of these basic distinctions in antiquity, see H. I. Marrou, A History of Education in Antiquity, trans. George Lamb (Madison: University of Wisconsin Press, 1956).

24 See Johann Gottfried von Herder, Philosophical Writings, trans. and ed. Michael N. Forster (Cambridge: Cambridge University Press, 2002), 22-27; and Aristotle, Selections, ed. W. D. Ross (New York: Charles Scribner's Sons, 1955), 318-23. 
and with which it has been in continual connection ... the fine arts and the sciences have grown up on that soil, and, while they have attained a selfsubsistence of their own, they have not yet emancipated themselves from the recollection of that older culture.... But, however important the preservation of this soil is, the modification of the relation between antiquity and modern times is no less essential. ${ }^{25}$ (my emphasis)

Instead of rejection and abolition, Hegel makes a case for modification and rework, or "digesting and transforming" the treasures of paideia, this "mother earth" of science and learning, through the vehicles of German language after a necessary phase of dialectical alienation and estrangement from both. ${ }^{26}$ Recall Dostoevsky's “detachment from the soil” (otorvannost' ot pochvy) and his "do not imitate, but continue" (PSS, 19:114). Like Hegel, Dostoevsky therefore supports the liberal arts and does not protest the return of classical curricula and the study of Russian in place of science initiated by Minister Dmitry Tolstoy. In objection to the avatars of professional and specialist training, he observes that Aristotle would never have become a great thinker had he started with techne and technology. Thank God he had started with The Iliad (Diary of a Writer, 1873; 21:129). Dostoevsky's constant recourse to Hegel's principle of Aufhebung ("sublation"), or the lifting of contradictions (sniatie protivorechii) and reconciling contradictions dialectically, is remarkable in its intended messianic sense: "We have adopted into our soul the geniuses of other nations, with love and in a friendly spirit rather than with hatred-all together, without discriminating them by their tribe. We were capable of discriminating, lifting all contradictions, practically from the very first step and by way of instinct, to forgive and to reconcile differences" (Diary of a Writer, $1880 ; 26: 147) .{ }^{27}$

Fichte's topical addresses structurally resemble Dostoevsky's answers to the enemies of Russia in his Diary of a Writer (this includes his answers to the anti-Russian militarism of Bismarck in 1877, which he blames on Luther's and

25 G. W. F. Hegel, Early Theological Writings, trans. T. M. Knox, with an introduction and fragments translated by Richard Kroner (Philadelphia: University of Pennsylvania Press, 1975), 321.

26 Ibid., 327.

27 See similar statements in Dostoevsky's chapter on Tolstoy's Anna Karenina (Diary of a Writer, July-August 1877): "Only Russian Spirit has been graced with universality [vsemirnost'], has been granted a mission to grasp and unite in the future the whole variety of nationalities, and to lift all of their contradictions" (PSS, 25:199). 
Kant's spirit of criticism) (PSS, 25:151-54). Substantively, Fichte's ideas resonate powerfully with Dostoevsky's ideas discussed in the earlier parts of this chapter. Fichte speaks about "thieving from the fruits of the soil" in the system of national education because of its being "ungrounded in the nature of things." So does Fichte's insistence that the new German education prepare its trademark citizens and human beings without the slackening of the reins of the state. ${ }^{28}$ Among the other drawbacks, Fichte names national and personal selfishness, complacency in times of peace, pursuit of ranks and comforts with the receipt of the sinecures afforded by specialty training, frivolous behavior and detachment from the demands of real life, and indifference to religion and to the historical mission of the land. ${ }^{29}$ Like Hegel and Humboldt, Dostoevsky identifies the power of the nation with the power of its language. Dostoevsky's notion of "language-nation" (iazyk-narod) (Diary of a Writer, June 1876; PSS, 23:8084) is a word-for-word borrowing of the phraseology of Herder and Humboldt on "cultivated" and "uncultured" tongues and their role in the formation of national languages, which define the success or failure of cultures. Humboldt is especially important. The founder of the University of Berlin has a whole chapter on the mental individuality of a people and the shape of its language and several chapters on how the efficacy of an individual suffers from lack of connection with the character of the people, disallowing each the achievement of Absolute Identity. ${ }^{30}$ Dostoevsky marches ahead of Humboldt by advancing the idea of the superiority of Russian language, even at its as yet uncultured stage, thanks to its alleged capacity for translating the universality of the absolute. "The deepest forms of the Spirit and thought of European languages," he argues, translate well in Russian, as imperfect as it might be, whereas the refined European languages and their best poets are unable to translate Russian artists. ${ }^{31}$ Despite these rather extreme pronouncements, they are a century-old remnant of Herder's insistence on the superiority of local color, however crude, a sort of

28 Johann Gottlieb Fichte, Addresses to the German Nation, ed., intro., and notes Gregory Moore (Cambridge: Cambridge University Press, 2008), 14-15, 22-24, 36, 124, 130.

29 See ibid.

30 See Wilhelm von Humboldt, On Language: On the Diversity of Human Language Construction and Its Influence on the Mental Development of the Human Species, ed. Michael Losonsky, trans. Peter Heath (Cambridge: Cambridge University Press, 1999), passim.

31 Dostoevsky laughed at the first European translations of Gogol (Diary of a Writer, June 1876; PSS, 23:80-84). 
messianism through imperfection. (Herder disputes Kant's arguments for teleological cosmopolitanism and the presence of international rather than only German vocabulary in philosophical discourse.) $)^{32}$

Humboldt's idea that the university should be responsible for the task of providing a well-rounded and well-grounded education to the nation in the state of constant advancement brings us to Dostoevsky's ideal, his "All-Man" (vsechelovek), a model endowed with philosophical, scientific, professional, and artistic knowledge, who would implement this knowledge for the good of society and whose motto is "to continue rather than imitate" (Ne podrazhat', a prodolzhat') (PSS, 19:114). However, Humboldt's persuasion that the university-or any other institution, or the state itself, for that matter-should exercise restraint when interfering in the affairs of education, limiting its solicitude to protecting the pedagogical well-being of a tutee, does not agree with the view of Dostoevsky, who thinks it false to "defend student youth from the government" $(21: 126) .{ }^{33}$ Dostoevsky has been shown above to be a huge supporter of solicitous violence against charges of misbehaving — even though protested against by Rousseau, Pestalozzi, Pushkin, Froebel, and most of other major thinkers whom he otherwise admires. In the words of Pestalozzi, one of the initiators of the prohibition of flogging, a young person, an individual, is a germ and a seed of humanity deserving of kind tending in order to grow. ${ }^{34}$

Dostoevsky praises the "living and independent spirit" of Pestalozzi's idea of the childhood garden and Froebel's idea of the kindergarten, but educational innovations and various scientific conventions assembled apropos are usually "rubbish," in his view (loose drafts for Diary of a Writer, PSS,

32 See the famous "paragraph 83" in support of cosmopolitanism, a form of maturity of humanity, its self-discipline in freedom, and the ultimate ends of humanity in history, in Immanuel Kant, The Critique of Judgment, trans. James Creed Meredith (Oxford: Oxford University Press, 1952), 92-97. Also on this score, see "The Idea for a Universal History with a Cosmopolitan Intent" (1784), in Immanuel Kant, Perpetual Peace and Other Essays, trans. Ted Humphrey (Indianapolis, IN: Hackett, 1983), 29-38. On Herder's objections, see "This Too a Philosophy of History for the Formation of Humanity," in J. G. von Herder, Philosophical Writings, trans. and ed. Michael N. Forster (Cambridge: Cambridge University Press, 2002), 272-358.

33 For a view opposite to Dostoevsky's, see Wilhelm von Humboldt, The Limits of State Action, ed. J. W. Burrow. (Indianapolis, IN: Liberty Fund, 1993), 46-52.

34 Heinrich Pestalozzi, The Education of Man, preface by William H. Kirkpatick; trans. Heinz and Ruth Norden (New York: Philosophical Library, 1951), 11-20, 57-64. 
$22: 146,148) .{ }^{35}$ In his novels and journalism, Dostoevsky, like Rousseau, Pestalozzi, and Froebel, often juxtaposes adolescents and young adults to children, who arrive at the most powerful insights thanks to their unspoiled and healthy instincts about life (Diary of a Writer, May 1876; PSS, 23:22; and 8:58, which is pt. 1 , ch. 9 of The Idiot). These ideas ring in strong accord with Rousseau and Pestalozzi (and with Schopenhauer and Nietzsche) in terms of Dostoevsky's concern for preserving independence from various commissions: "It is bad if [independence] turns into something purely institutional ... the beginning is naive, and then there is an organization" (Diary of a Writer, drafts $1876 ; 22: 146)$.

The question of institution as a form of authority is therefore important. Dostoevsky's solution is ultimately a losing one if judged by his messianic program's checklist for success. The national education of which he dreams is dependent on stable institutions and on what Hegel calls "incorporation" (Einbildung), the summit of upbringing in a strong national state. This is the absolute value of education, amounting to the "cultivation of the universality of thought" and the "incorporation of reason into reality which the whole of world history has worked to achieve." ${ }^{36}$ So understood and implemented, the incorporation entails the rationalization of education and training that creates the bureaucracy of specialists, a privileged caste with aspirations for proper remuneration, who are not the same as the cultivated men reared in the ideas of messianism.

As Max Weber puts it, educational certificates do not create the conditions for democracy, but for professional meritocracy. ${ }^{37}$ Dostoevsky's guardedness vis-à-vis the necessity of institutions (uchrezhdeniia) undermines his messianic project, which would otherwise have been like Hegel's, the sublimation or fulfillment of Russian (rather than Prussian) incorporation in world history. His guarded behavior around institutions is his fear of German barbarism, equivalent to Weber's fear of "the iron cage" - what Durkheim would

35 On Froebel's child-centered pedagogy in the kindergarten, see F. W. Froebel, The Education of Man, trans. W. N. Hailmann (New York: Dover, 2005), and R. B. Downs, Friedrich Froebel (Boston: Twayne, 1978).

36 G. W. F. Hegel, Elements of the Philosophy of Right, trans. H. B. Nisbet, ed. Allen W. Wood. (Cambridge: Cambridge University Press, 1991), 52, 294-95.

37 Max Weber, From Max Weber: Essays on Sociology, trans., ed., and intro. H. H. Gerth and C. Wright Mill (Oxford: Oxford University Press, 1975), 240-43. 
juxtapose, as a case of the failure of German Bildung, to the healthy humanism derived by other national traditions and systems of education from organic pagan cultures, such as the Greeks and the Romans. ${ }^{38}$ In the steady displays of his fear against state bureaucracy, which he shares with the Slavophiles, most notably K. S. Aksakov, Dostoevsky also displays his caring humanism, what Durkheim calls "Christian habits of the soul," which agrees with the tradition inherited from the Renaissance humanism of Rabelais and sentimentalist humanism of Rousseau. ${ }^{39}$ Prophetic humility could be the reason why Dostoevsky, to confirm Bakhtin, prefers a loophole approach to sanctimonious preaching in pedagogical matters. ${ }^{40}$

Another aspect of the failing authority of Dostoevsky's messianism is disclosed in Hannah Arendt's explanation of the crises-laden approaches to education by the extreme "new ones." By "new ones" she means the newbies of modern civilization. (Arendt concentrates on the United States, but her explanation is perfectly applicable to Russia, whose construction of the modern educational project is also starting within the framework of the eighteenth century.) There is always a danger with the newbies, these disciples of Rousseau, as Arendt understands it, for confusing education with politics and for making education "an instrument of politics." ${ }^{41}$ The result of this confusion is a disastrous failure of persuasion, which invites "dictatorial interference." 42 More directly on the same issue is what Gadamer has to say about authority, about the confusion of the question of the authority of the teacher based on knowledge, pedagogical skill, and intellectual integrity with authoritarianism. Russia and Germany of the twentieth century serve up an example of "Enlightened barbarianism" and totalitarian appropriation of the program

38 On the barbarism and failure of German Bildung built off Protestantism and moral rationalism, see Emile Durkheim, “The Social Bases of Education," in Selected Writings, ed. Anthony Giddens (Cambridge: Cambridge University Press, 1972), 203-18.

39 Ibid., 207.

40 On the topic of education, Dostoevsky was especially reluctant to speak "in essences" (essentsiami) (Diary of a Writer for 1873, "Riazhenyi"; PSS, 21:88), but in his preferred method of "words with a loophole" (ibid.)

41 Hannah Arendt, "The Crisis in Education," in Between Past and Future, intro. Jerome Kahn (New York: Penguin Classics, 1968), 170-93, esp. 173-77 and 186. The US crisis of failure, according to Arendt, is a conflict between its original principles of equality and democracy and the principles of meritocracy necessarily present in modern systems of education.

42 Ibid., 173. 
that had started on more innocent notes of messianic superiority among the Aryan nations. ${ }^{43}$

This is a fruitful conflict that can help to penetrate Dostoevsky's messianism from yet another angle. By recovering the idea of the care of life as the care of self, Dostoevsky returns to principles of premodern Russian Christian learning, which concentrate on the building of the soul through the guidance obtained from shepherds and holy books. In this case, Dostoevsky complies with Durkheim's solution for perfect shepherding, in which a spiritual shepherd prepares the healthy sociological future for his nation. ${ }^{44}$ By endorsing the healthy social bases of education originating from religion and spirituality-they stifle modern anomie in its cradle-Durkheim is notably excluding extreme nationalism, which he ascribes to the very controlling barbarism of Germany. In this regard, François Lyotard considers Martin Heidegger, the Nazi-appointed rector of Freiburg in 1933. A comparison suggested by Lyotard is useful: before embracing extreme nationalism, Heidegger had accepted that pedagogy is a form of relentless questioning of being. For the nationalistic Heidegger, as Lyotard aptly sums up, "the questioning of being becomes a conversation on the 'destiny' of historico-spiritual people." ${ }^{45}$ Unsurprisingly, the Fichte of 1933 unfolds a threefold mission of the National Socialism-led Bildung, in which learning trails behind at a distant third position after military service and labor, allowing the nationalistic party "to assume direct control over the training of the "people." 46

Unlike his fiction, Dostoevsky's political program for education supplies the Russian state with a comparably dangerous narrative. Schiller was the first to warn against the conflation of pedagogical and political acts and the

43 Hans-Georg Gadamer, "Authority and Critical Freedom," in The Enigma of Health. The Art of Healing in a Scientific Age, trans. Jason Gaiger and Nicholas Walker (Stanford, CA: Stanford University Press, 1996), 117-24.

44 Durkheim, “Social Bases of Education," 217.

45 Jean-François Lyotard, The Postmodern Condition: A Report on Knowledge, trans. Geoff Bennington and Brian Massini, foreword by Fredric Jameson (Minneapolis: University of Minnesota Press, 1984), 37.

46 Ibid., 32. See Martin Heidegger, German Existentialism, trans. and intro. Dagobert D. Runes (New York: The Wisdom Library, 1965), 13-19. In this regard, it is meaningful that the turnof-the-century and the early Weimar Republic German admirers of Dostoevsky-Musil, Mann, Hesse, Benjamin—all became political émigrés who had chosen not to live under Nazism. 
application of artisanal violence to matter. Schiller distinguishes between barbarism (rationalistic and doctrinaire application of violence) and savagery (where the violent action springs from emotion and feeling). ${ }^{47}$

In the context of this conversation on shepherding as an attempt of forming, it is important to remember Martin Buber's idea of religious dialogue: "Man, the creature, who forms and transforms the creation, cannot create. But he, each man, can expose himself and others to the creative Spirit. And he can call upon the Creator to save and perfect His image." ${ }^{48}$ Buber's is a preventive response to "shaping" the destiny of individual people and nations by means of casting them into nationalistic molds. Such programs do not bring a pupil faceto-face with God, nor is dialogue with the divine achieved by peeping through a Menippean loophole.

The possibility of truth is subject to cautious withholding for reasons other than polyphony. In the words of Karl Jaspers, education in the universities has forfeited its original purpose of being a "possible safeguard of truth against the reality of the state." By becoming the servants of nationalism, they betrayed their eternal idea: "The responsibility of the university as a Western, supranational and suprapolitical idea was lost." ${ }^{49}$ For existentialists like Jaspers, forfeiting the authority of educational institutions only increases the value and responsibility of the behavior of lonely selves caught in the limits of life's situations. If the educational institution and the state cease to offer choices to the individual, the individual should nonetheless traverse the spaces of existence.

The spaces of postmodern existence extinguish grand narratives, the narratives which become delegitimized, along with institutions that supported it: be it nation states, permanent professions, historical traditions or iconic institutions, including the new messianism. ${ }^{50}$ There is no hope for organic society in the reality of systems that regulate performativity in which language

47 See letter 3 in Friedrich Schiller, On the Aesthetic Education of Man: In a Series of Letters, ed. and trans. with an introduction and commentary by Elizabeth M. Wilkinson and L. A. Willoughby (Oxford: Clarendon, 1982), 10-15.

48 The quote comes from an address that Buber delivered on "the matter of education," "Rede über das Erzieherische," at the Third International Educational Conference held at Heidelberg in August 1925; see Martin Buber, Between Man and Man, trans. Ronald Gregor Smith (Boston: Beacon Press, 1961), 103.

49 Karl Jaspers, Philosophy and the World: Selected Essays and Lectures (Washington, DC: Regnery Gateway, 1963), 247.

50 Lyotard, Postmodern Condition, 15-17. 
is a game of pragmatic means. Worst of all, a human being cannot be educated or developed, being "already positioned as the referent in the story recounted by those around him. ${ }^{51}$ In the global age where we live today, what is the relevance for Dostoevsky's messianism? I see it as still relevant, both negatively and positively.

Negativity first. Let us look at the question of shepherding and authority from the perspective of youthful rebellion. The young Benjamin credits Dostoevsky with understanding the crux of the conflict in modern society, which is the generational face-off between the educators and the educated, the grown-up world and the world of radicalizing youth: "In pursuit of its goal, humanity continually gives birth to an enemy: its young generation, its children, the incarnation of its instinctual life, of its individual will, the properly animal part of its existence, its continually self-renewing past." ${ }^{2}$ Hence, there is no more important task for humanity than to appropriate this youthful existence, to introduce it into the process of human development before it becomes a vehicle of terror. "This is the function of education," writes Benjamin. ${ }^{53}$

As much as he abhors radicalism, Dostoevsky enters into a contest with a generation of revolutionary-minded students of the 1860 s and 1870s, telling them angrily that members of the Petrashevsky circle to which he had belonged had not only been better educated but also more determined to die for their ideals (Diary of a Writer, January 1877; PSS, 25:23-26).$^{54}$ In his response to Miliukov in 1878, Dostoevsky thinks of radical youth clearly as an enemy of the Russian Orthodox Christians: "Last winter, during the Kazan Railway affair, a throng of youth defiles the Temple of our Nation, smokes cigarettes in church, and instigates a scandal. Listen, I'd like to say to these Kazansky Railway marcher boys ... you do not believe in God, this is your trouble, but why do you insult the narod and his Temple? And so the

51 Ibid.

52 Benjamin, "Dostoevsky's The Idiot," 40.

53 Ibid.

54 During his detention in the Peter and Paul Fortress, Dostoevsky claimed that the education of the fellow Petrashevsky circle members, steeped in the ideals of libertarian Enlightenment, posed no danger to the state (PSS, 18:120). 
narod called them 'noble brats' and, worse than that, stigmatized them as 'students,' but truth be told, there were quite many Jews and Armenians in there (so it is proven, that the demonstration is political and arranged by external force)" (30[1]:23).

And now the positivity, in its plural senses. Regarding the question of enlightenment, Dostoevsky can be said to prefigure Foucault in not conflating enlightenment with humanism because-and despite his support of authoritarianism-he believed that correct methods of education are not expressed through discourses of power, but through the effort of the entire Russian nation. Enlightenment for both Dostoevsky and Foucault involves primarily a test of "problematization of being" and the following questions: "How are we constituted as subjects who exercise or submit to power relations? How are we constituted as moral subjects of our own actions?" ${ }^{55}$ But whereas for Foucault the test that requires work on "our limits" is a "patient labor giving form to our impatience for liberty," ${ }^{\prime 6}$ the same would be for Dostoevsky a patient labor for God, since the proverbial "impatience for liberty" is the very problem he identifies with Western enlightenment.

It can be said that Dostoevsky's messianism leads to undesired results (undesired by him, that is). He did not design his Underground Man to be a warning against institutions. He wanted his paradoxalist to perpetuate his condemnation of the loss of Christian humility and an inability to achieve redemption by suffering with and for another. In the West, the type is none of the above: it is a postmodern emblem of ironic decentering and displacement in disguise, best summarized in Gilles Deleuze's concepts of pure difference and complex repetition. Deleuze thinks that in the times of the loss of history, the Underground Man teaches us to be untimely. At the risk of "playing the idiot, do so in the Russian manner: that of an underground man who recognizes himself no more in the subjective presuppositions of a natural capacity for thought than in the objective presuppositions of a culture of the times, and lacks the compass with which to make a circle. Such a one is Untimely, neither

55 Michel Foucault, "What Is Enlightenment?," in The Essential Foucault, ed. Paul Rabinow (New York: New Press, 1994), 56-57.

56 Ibid., 57. 
temporal, nor eternal." ${ }^{57}$ Thus Dostoevsky's messianic pursuit of "All-Knowledge" through constant reauthoring "with a difference" of what is borrowed is misappropriated in the intellectual mainstream of the West. Deleuze and other Western postmodernists take Dostoevsky's message for the warning against "overfull understanding," 58 a means to protect one's subjectivity from knowing all and knowing like all.

A shepherd is judged in his art by "nothing else than how to provide what is best for that over which it is set," says the master of loophole wisdom, Socrates. ${ }^{59}$ Was Dostoevsky a good shepherd or an evil prophet, the purveyor of Aristotle's tokos ("interest gained off offspring") or chrematics ("artificial, bad, mercantile mentoring") $?^{60}$ Did he gain a fair rate in receiving the interest off the offspring that was good ${ }^{61}$ From the doctrinal point of view of Russian Orthodoxy, a writer cannot be a shepherd. The institute of shepherds is not a mere branch of pedagogical leadership broadly understood, but a consecrated and ordained clerical duty. ${ }^{62}$ Dostoevsky's shepherd also bears no likeness to the sinister conductors and leaders of the twentieth century, whom he had predicted with horror in a whole gallery of characters, especially in the monstrous Verkhovensky. What is known for sure is that Dostoevsky's art spawns a generous offspring in the complex repetition of other big artists. In this regard, the effusive lyricism of Robert Musil's Young Törless, which echoes the confusions of Arkady Dolgoruky in Dostoevsky's Adolescent, reaffirms the existence of indwelling goodness in the native soil of world literature:

57 Gilles Deleuze, Difference and Repetition, trans. Paul Patton (New York: Columbia University Press, 1994), 130.

58 Ibid.

59 See Republic 345d (bk. 1), in Plato, The Collected Dialogues, ed. Edith Hamilton (Princeton, NJ: Princeton University Press, 1961), 595.

60 See Marc Shell, The Economy of Literature (Baltimore: Johns Hopkins University Press, 1978), $24,46$.

61 Plato, Republic 507a (bk. 4); 742.

62 See Metropolitan (Mitropolit) Antonii, Uchenie o pastyre, pastyrstve i ob ispovedi, intro. Archbishop Nikon (Ryklitsky) (New York: Izdatel'stvo Severo-Amerikanskoi i Kanadskoi Eparkhii, 1966). It will be recalled that Alyosha Karamazov leaves the monastery and does not attend the seminary after organizing his notes of Zosima's instructions. Dostoevsky believed seminaries to be training grounds for unthinking herd or future radicals, as reflected in his notebooks for 1875-77 (PSS, 24:67). 
He had a longing for silence, for books. As though his soul was black earth, beneath which the seeds are stirring, and no one knows how they will break forth. The image of a gardener occurred to him, watering his flower-beds each morning, with even, expectant care. That image wouldn't let him go, its expectant certainty seemed to attract all his yearning to itself. ... All his reservations ... were swept aside by the conviction that he must stake everything on achieving that state of mind. ${ }^{63}$

"Man and plant blossom differently", says Humboldt. ${ }^{64}$ Musil's hero, who-like his author-leaves the military academy to become a writer as a result of his contemplation about the black soil in the care of a good gardener, is only following in the footsteps of Fyodor Dostoevsky, graduate of the Academy for Military Engineering.

63 Robert Musil, The Confusions of Young Törless, trans. Shaun Whiteside, intro. J. M. Coetzee (London: Penguin, 2001), 146.

64 Humboldt, Limits of State Action, 13. 
